\title{
AS DISPUTAS EM TORNO DO MINISTÉRIO DA AGRICULTURA, INDÚSTRIA E COMÉRCIO E A CONFECÇÃO DA PRIMEIRA LEI DE ENSINO AGRÍCOLA NO BRASIL
}

\author{
Marco Arlindo Amorim Melo Nery ${ }^{1}$
}

\section{RESUMO}

No início do século XX, A Sociedade Nacional de Agricultura (SNA) cobrava do governo central a criação de uma política agrícola que atendesse as demandas agrícolas, dentre elas a formação de mão de obra. Nesta direção, o governo criou o Ministério da Agricultura, Indústria e Comércio (1906), o qual foi foco de disputas entre parte da elite agrária paulista e integrantes da SNA. Tais disputas deram origem ao decreto $\mathrm{n}^{\circ} 8.319$ de 1910 , sendo a primeira lei do ensino agrícola brasileira, que refletiu experiências de países europeus, dos Estados Unidos e da própria experiência do estado de São Paulo, configurando-se numa lei marcada por um pensamento pragmático.

Palavras-chave: Ministério; Lei; Ensino Agrícola

\section{DISPUTES AROUND THE MINISTRY OF AGRICULTURA, INDUSTRY AND TRADE AND THE MAKING OF AGRICULTURAL EDUCATION LAW FIRST IN BRAZIL}

\begin{abstract}
In the early 20th century, The National Society of Agriculture ( SNA ) charged the central government to set up an agricultural policy that would meet agricultural demands, among them the formation of specialised workers. In this direction, the government created the Ministry of Agriculture, Industry and Trade (1906 ), which was the focus of disputes between portion of São Paulo agrarian elite and SNA members. Such disputes have led to Decree $n^{\circ} 8319$ of 1910, the first law of Brazilian agricultural education, which reflected the experiences of European countries, the United States and the experience of São Paulo, setting up a law marked by a pragmatic thinking .
\end{abstract}

Keywords : Ministry ; Law; Agricultural education

\section{Introdução}

Desde 1902 a Sociedade Nacional de Agricultura (SNA), por intermédio de dois dos seus representantes na Câmara dos Deputados Federais, buscava aprovar o projeto de criação do Ministério da Agricultura, Indústria e Comércio, sendo, inclusive, um dos elementos tratados, no ano anterior, no I Congresso Nacional de Agricultura. Contudo, a aprovação do decreto de criação do MAIC somente se materializou no ano de 1906, durante a presidência de Afonso Augusto Moreira Pena ${ }^{2}$.

Essa demora entre a propositura do decreto e sua aprovação deveu-se ao fato de que integrantes da oligarquia cafeeira paulista, assolados com a baixa do preço de alimentos e demais produtos agrícolas, em especial o café, que se agravava desde fins dos oitocentos, observavam a criação do MAIC como uma ameaça à distribuição de recursos públicos, que já acreditavam escassos para suprir as demandas da agricultura cafeeira (MENDONÇA, 1997). 
Isso fez com que os cafeicultores paulistas utilizassem todo o seu prestígio político e econômico para "barrar" a criação do MAIC, principalmente junto ao presidente da época, Francisco de Paula Rodrigues Alves ${ }^{3}$ (1902-1906), este que, apesar de ter nascido no Rio de Janeiro, constituiu-se como político em São Paulo desde o Império, ocupando todos os postos possíveis (deputado, senador, presidente).

Todavia, a crise do café agravava-se com o passar dos anos, pois seu preço caía assustadoramente no mercado internacional e, diante de uma safra recorde prevista para o ano de 1906, cafeicultores paulistas convocaram uma reunião dos estados produtores com o intuito de firmar um acordo estabelecendo-se o controle estatal sobre os preços do produto. Tal convênio, assinado em 1906 pelos presidentes dos estados de Minas Gerais, Rio de Janeiro e São Paulo, denominou-se Convênio de Taubaté (MENDONÇA, 2008).

A assinatura desse convênio com a anuência do governo federal causou uma série de questionamentos na Câmara Federal, principalmente de parlamentares eleitos pelo Distrito Federal e por estados do Nordeste que utilizavam o argumento de que:

o Convênio consolidaria a desigualdade entre grandes e pequenos estados, sendo estes últimos os maiores prejudicados, já que a União se sobrecarregaria de compromissos para beneficiar apenas algumas poucas unidades da Federação (MENDONÇA, 2008, p. 87).

Essa contenda entre os representantes da oligarquia paulista e integrantes de outros centros de menor poder econômico culminou num acordo que permitiu a aprovação de alguns termos do convênio que competiam à União e a aprovação do decreto 1.606 de criação do MAIC.

Como aludido anteriormente, a criação do MAIC deu-se na gestão de Afonso Pena, tendo como vice-presidente Nilo Peçanha. Este último foi um ardoroso defensor da atuação estatal em todos os setores da produção agrícola, e, diante da conjuntura política anunciada com a morte de Afonso Pena, tornou-se um dos principais articuladores da campanha de Hermes da Fonseca à presidência da república, em oposição aos civilistas, representados principalmente pelos paulistas que encamparam a candidatura Rui Barbosa (MENDONÇA, 1997). Desta forma, os momentos de criação do ministério (1906) e posterior implantação (1909) estiveram submersos nessa conjuntura.

O decreto de criação do MAIC definia as responsabilidades da pasta, dividindo-a em três ramos: a Agricultura e Indústria Animal, a Indústria e o Comércio. Todavia ficava evidente a predominância das questões ligadas à agricultura frente às da indústria e Comércio. Neste sentido, das 22 atribuições do novo ministério, 11 estavam relacionadas ao ramo da Agricultura e Indústria Animal e, dentre as atribuições dos outros dois ramos havia aqueles diretamente relacionados ao meio agrícola.

$\mathrm{Na}$ área da Indústria, cinco atribuições previstas no decreto $\mathrm{n}^{\mathrm{o}} 1.606$, uma, em especial, guardava relação direta com o setor primário da economia, a "conservação e reconstituição das florestas e matas compreendidas as da indústria extrativa, execução dos regulamentos concernentes à pesca nos mares territoriais e rios do domínio federal" (BRASIL. Decreto 1.606 de 29/12/1906).

Em relação ao Comércio, dentre as seis atribuições citadas na lei, duas mantêm relação com o setor agrícola, no tocante à responsabilidade por organizar exposições agrícolas e a de efetuar estudos econômicos "das vias férreas, em suas relações com a agricultura em todos os estados, estradas de rodagem, custo dos transportes, acondicionamento, embalagem, seguros, fretes e tarifas" (IDEM). 
O decreto indicava, ainda, que toda e qualquer instituição, estabelecimento e repartição pública que guardassem relação com as áreas de atuação do MAIC deveriam passar para sua responsabilidade, a exemplo do Observatório Astronômico do Rio de Janeiro, da Repartição de Estatística e Estatística Comercial, do Jardim Botânico, a Escola de Minas, o Museu Nacional, a Hospedaria da Ilha das Flores e a Fábrica de Ferro do Ipanema (IDEM).

A implantação do MAIC, levada a cabo na breve gestão de Nilo Peçanha (19091910), apesar de contrariar os interesses da oligarquia paulista, agradava-lhe ao ser conduzido ao comando da pasta o ex-secretário da agricultura de São Paulo, o engenheiro militar Antônio Cândido Rodrigues. Entretanto, as pressões advindas da campanha presidencial fizeram com que alguns órgãos de imprensa, a exemplo do jornal carioca $O$ Paiz, de forma irônica, parabenizassem o governo federal pela escolha de um civilista para ocupar a pasta da Agricultura (O PAIZ apud MENDONÇA, 1997).

As pressões exercidas por setores da imprensa e por políticos empenhados na campanha de Hermes da Fonseca fizeram com que a passagem de Cândido Rodrigues à frente do MAIC fosse curtíssima, sendo no mesmo ano de 1909 destituído do posto. Contudo, para aplacar os ânimos dos paulistas, o presidente Nilo Peçanha indicou para a pasta outro paulista, Rodolfo Nogueira da Rocha Miranda, dissidente do Partido Republicano Paulista e um dos articuladores da campanha hermista no estado de São Paulo. Embora sua gestão também tenha sido curta (1909-1910), executou a primeira reforma do MAIC buscando organizar melhor a sua estrutura burocrática, definindo as atribuições de cada setor.

Sucedendo a Rodolfo Miranda, assumiu outro paulista, também defensor da candidatura Hermes da Fonseca para presidente, Pedro de Toledo (1910-1913), que encerrou o que Mendonça (1997) denominou de o "interlúdio paulista" à frente do Ministério da Agricultura, Indústria e Comércio.

Após o "interlúdio paulista" no MAIC, os dirigentes da pasta, até o ano de 1930, foram provenientes dos estados do Rio de Janeiro, Minas Gerais e, principalmente, de estados do Nordeste, à exceção do período compreendido entre 1918-1919, no qual ocupou a pasta o engenheiro e bacharel paulista Antônio de Pádua Sales.

\section{QUADRO 1 - DIRIGENTES DO MAIC ENTRE 1909 E 1947}

\begin{tabular}{|c|c|c|c|c|}
\hline $\mathrm{N}^{\circ}$ & Nome & Procedência & Formação & Período em que foi Ministro \\
\hline 1 & Antônio Cândido Rodrigues & SP & $\begin{array}{l}\text { Engenheiro } \\
\text { militar }\end{array}$ & 19/06/1909 a 26/11/1909 \\
\hline 2 & Rodholpo N. da Rocha Miranda & SP & ----- & 26/11/1909 a 15/11/1910 \\
\hline 3 & Pedro Manuel de Toledo & SP & $\begin{array}{c}\text { Bacharel em } \\
\text { direito }\end{array}$ & 15/11/1910 a 18/11/1913 \\
\hline 4 & Manoel Edviges Queiroz Vieira & RJ & $\begin{array}{c}\text { Bacharel em } \\
\text { direito }\end{array}$ & 19/11/1913 a $15 / 11 / 1914$ \\
\hline 5 & João Pandiá Calógeras & RJ & $\begin{array}{l}\text { Engenheiro } \\
\text { geólogo }\end{array}$ & 15/11/1914 a 07/08/1915 \\
\hline 6 & José Rufino Bezerra Cavalcanti & PE & $\begin{array}{c}\text { Engenheiro e } \\
\text { bacharel }\end{array}$ & 07/08/1915 a 26/11/1917 \\
\hline 7 & João Gonçalves Pereira Lima & $\mathrm{PE}$ & Engenheiro & 26/11/1917 a $12 / 12 / 1918$ \\
\hline 8 & Antônio de Pádua Sales & SP & $\begin{array}{c}\text { Bacharel em } \\
\text { direito }\end{array}$ & 12/12/1918 a 28/07/1919 \\
\hline 9 & Ildefonso Simões Lopes & RS & Engenheiro & 28/07/1919 a 24/05/1922 \\
\hline 10 & $\begin{array}{l}\text { José Pires do Rio } \\
\end{array}$ & RJ & Engenheiro & $24 / 05 / 1922$ a $15 / 11 / 1922$ \\
\hline 11 & Miguel Calmon Du Pin e Almeida & BA & Engenheiro & 15/11/1922 a 15/11/1926 \\
\hline
\end{tabular}




\begin{tabular}{|c|c|c|c|c|}
\hline 12 & Germiniano Lira Castro & PA & Médico & $15 / 11 / 1926$ a 23/10/1930 \\
\hline 13 & Paulo de Moraes Barros & SP & Médico & $23 / 10 / 1930$ a 18/11/1930 \\
\hline 14 & Joaquim Francisco de Assis Brasil & RS & $\begin{array}{c}\text { Bacharel em } \\
\text { direito }\end{array}$ & $18 / 11 / 1930$ a 22/12/1932 \\
\hline 15 & Juarez Távora & CE & Militar & $22 / 12 / 1932$ a 24/07/1934 \\
\hline 16 & Odilon Duarte Braga & MG & $\begin{array}{c}\text { Bacharel em } \\
\text { direito }\end{array}$ & $24 / 07 / 1934$ a 13/11/1937 \\
\hline 17 & Fernando de Sousa Costa & SP & Agrônomo & $13 / 11 / 1937$ a 03/06/1941 \\
\hline 18 & Carlos de Sousa Duarte & ES & Agrônomo & $03 / 06 / 1941$ a 18/02/1942 \\
\hline 19 & Apolônio Jorge de Farias Sales & PE & Agrônomo & $19 / 02 / 1942$ a 29/10/1945 \\
\hline 20 & Teodureto Leite de A. Camargo & SP & Agrônomo & $08 / 11 / 1945$ a 31/01/1946 \\
\hline 21 & Manoel Neto Campelo Júnior & PE & $\begin{array}{c}\text { Bacharel em } \\
\text { direito }\end{array}$ & $31 / 01 / 1946$ a 15/10/1946 \\
\hline 22 & Daniel Serapião de Carvalho & MG & Advogado & $15 / 10 / 1946$ a 27/04/1950 \\
\hline
\end{tabular}

Fonte: Disponível em <www.agricultura.gov.br〉, acesso em 23 de mai. 2009.

De acordo com esse quadro, numa análise que leve em consideração o período compreendido entre os anos 1909 e 1947, percebe-se a predominância de dirigentes advindos do estado de São Paulo (31,81\%), figurando em segundo lugar o estado de Pernambuco $(18,18 \%)$, o que demonstra, a despeito da influência da SNA na constituição do MAIC, a força política e econômica dos paulistas. Todavia, compreendendo como Mendonça (1997) que havia uma disputa pelo controle da pasta da agricultura federal entre São Paulo e os demais estados brasileiros representados pela SNA, vê-se uma predominância desse segundo grupo $(68,18 \%)$, fato que denota a influência da Sociedade sobre o ministério.

Vale ressaltar que no período entre 1909 e 1947 houve uma predominância de engenheiros e bacharéis em direito à frente da pasta, num total de sete cada $(38,81 \%)$. Entretanto, caso levemos em consideração que os agrônomos também faziam parte de um grupo de profissionais que tratavam da aplicação da ciência, ou seja, de um saber pragmático, têm-se que estes representaram metade da ocupação do ministério no mencionado período.

Contudo, caso analisemos apenas o período compreendido entre 10 de novembro de 1937 e 29 de outubro de 1945, denominado de Estado Novo, no qual ocuparam a pasta da agricultura quatro profissionais, percebemos a hegemonia de agrônomos ocupando o ministério, correspondendo em termos relativos com $75 \%$ das indicações. Este fato pode estar relacionado ao reconhecimento por parte do Estado da profissão de engenheiro agrônomo, ocorrida em 12 de outubro 1933, através do decreto $\mathrm{n}^{\circ}$ 23.196, assinado durante a gestão do ministro Juarez Távora ${ }^{4}$. Isto também denota a perspectiva de especialização técnica adotada pelo governo estadonovista.

Outro aspecto que se depreende do quadro 1 é a grande rotatividade dos dirigentes da pasta, o que reflete as instabilidades que marcaram a história política brasileira. Entretanto, evidencia-se que a gestão mais duradoura à frente da pasta foi do engenheiro baiano Miguel Calmon Du Pin e Almeida ${ }^{5}$, que havia deixado a presidência da SNA para assumir o MAIC.

A gestão de Miguel Calmon à frente do Ministério da Agricultura intensificou um processo de reorganização do ministério, que já vinha sendo empreendido desde 1915, com o intuito de simplificar e dar maior dinamicidade às atividades técnico-científicas da pasta. A reestruturação empreendida por Calmon marcou um recrudescimento do viés pragmático do MAIC ao se acentuarem os discursos racional e científico, dando continuidade às reformas iniciadas durante a gestão de outro membro da SNA, o engenheiro e rizicultor 
gaúcho, Ildefonso Simões Lopes ${ }^{6}$, que, durante seu período à frente da pasta da agricultura, tornou obrigatória a formação agronômica para a ocupação de cargos técnicos no ministério (BRASIL-RMAIC, 1919).

A gestão de Ildefonso Simões Lopes [...] foi o marco inaugural da institucionalização de uma tendência destinada a promover a todo custo a 'modernização' agrícola do país sob a égide da racionalidade produtiva e da incorporação de novas fronteiras à órbita da produção mercantil (MENDONÇA, 1997, p. 143).

Neste sentido, as gestões de Ildefonso e Calmon à frente do MAIC são significativas para demonstrar a influência da SNA no aparelho estatal. Ao longo dos sete anos em que permaneceram na gestão do MAIC, Ildefonso Lopes e Miguel Calmon foram responsáveis pela conversão do Serviço de Inspeção e Defesa Agrícola em Serviço de Inspeção e Fomento Agrícola (1920); do Departamento Nacional do Trabalho em Conselho Nacional do Trabalho (1923); da criação do Serviço Expurgo de Cereais (1920); do Serviço de Cooperação Agrícola (1920); da Superintendência de Abastecimento (1920); do Serviço de Fiscalização de Caixas Rurais (1925) e da recriação do Serviço do Algodão (1920), que havia sido criado em 1915 e extinto em 1916 por pressão dos produtores paulistas (BRASIL-RMAIC, 1915-1930 e MENDONÇA, 1997).

Foi também na gestão desses dois ministros que se deu impulso às pesquisas na área de combustíveis, tendo o Serviço Geológico como veículo desta iniciativa, almejando-se, com isso, a extração de petróleo e de carvão mineral (BHERING, 2008).

Muito embora as iniciativas em prol do desenvolvimento e modernização da agricultura tenham sido muitas, numa clara tentativa de inserção do Estado nas questões agrícolas, o MAIC não dispunha de um orçamento grandioso para poder dar cabo aos seus projetos. É tanto que entre 1909 e 1930, dos sete ministérios existentes (Interior, Relações Exteriores; Marinha; Guerra; Viação e Obras Públicas; Fazenda e Agricultura, Indústria e Comércio), o do MAIC era o segundo menor, estando à frente apenas do de Relações Exteriores (BRASIL-RMF, 1909-1926; BRASIL, Coleções de Leis da República 18901930).

A despeito das dificuldades de condução dos projetos, em virtude da escassez orçamentária, o MAIC teve uma função essencial no que tange à difusão do discurso de modernização do campo, através da adoção de uma agricultura racional, fundamentada em padrões científicos. Para tanto, uma das seções, dentro da estrutura do ministério, que recebia maior atenção em termos de distribuição de recursos era a de Ensino Agronômico (BRASIL-RMAIC, 1910-1930).

Outra medida do ministério iniciada a partir de 1918, a qual também está relacionada à difusão de técnicas agrícolas modernas, foi a capacitação de agrônomos brasileiros em outros países, especialmente nos Estados Unidos da América, onde em 1928 havia 138 estudantes-bolsitas, distribuídos por aquele país, especialmente em duas Universidades, a de Illinois, em Urbana, que tinha por foco o ensino de química, mecânica e eletricidade aplicados à agricultura, e a Escola do Texas, que tinha várias culturas experimentais semelhantes às brasileiras (BRASIL-RMAIC, 1918-1928).

Além dessa iniciativa, o MAIC buscava nos EUA a aquisição de máquinas e insumos agrícolas, demonstrando a propensão brasileira pela adoção do modelo pragmático norte-americano de desenvolvimento agrícola. Sobre a experiência norte-americana, assevera Lauren Soth: 
Em um século e meio a fazenda norte-americana transformou-se completamente. A força do músculo foi substituída pela da máquina, de muito maior eficiência. A pesquisa em larga escala, patrocinada por entidades públicas, possibilitou melhores produções - animal e vegetal - e aperfeiçoou técnicas para fomentá-las. Um plano de ensino especializado, sem paralelo na história disseminou amplamente esses conhecimentos (1968, p. 12).

Era essa experiência de sucesso que o MAIC queria ver reproduzida no Brasil e, para tanto, necessitaria criar uma rede de estabelecimentos de ensino e outras instituições de difusão científica que pudessem disseminar a moderna agricultura em diversos pontos do país. Desta forma, já no ano de 1910, através do decreto 8.319, criou e baixou regulamentação para o ensino agrícola.

\subsection{Criação e regulamentação do ensino agronômico}

$\mathrm{Na}$ esteira das iniciativas modernizantes pensadas para a agricultura brasileira desde o século XIX, uma das mais recorrentes era a criação, por parte do Estado, de uma rede de estabelecimentos que pudesse formar e qualificar a mão de obra agrícola. Desde os congressos agrícolas de 1878 já havia cobranças de setores da agricultura brasileira nessa direção.

Essas pressões, no entanto, foram intensificadas a partir da criação da Sociedade Nacional de Agricultura (SNA), que defendida a implantação do ensino agrícola por parte do governo federal como uma das formas de superar o "atraso agrícola" em que se encontrava o país. Neste sentido, a criação do MAIC foi de extremo significado, pois seria através dele que emanariam as políticas agrícolas e, em especial, as políticas para o ensino agrícola.

Com o intuito de responder aos reclamos vindos do campo, o presidente Nilo Peçanha, na gestão do ministro Rodolpho da Rocha Miranda, através do decreto $\mathrm{n}^{\circ} 8.319$, de 20 de outubro de 1910, instituiu e normatizou o ensino agronômico brasileiro, tendo por base o modelo norte-americano (MENDONÇA, 1997; BHERING, 2008).

Outrossim, não posso afirmar que apenas o modelo norte-americano serviu como exemplo para o ensino agronômico brasileiro, haja vista a participação marcante de europeus advindos da França, Bélgica, Alemanha, dentre outros países, que compuseram os quadros docentes de diversas instituições de ensino. Defendo, portanto, a ideia da adoção de um modelo disperso, que incorporou experiências norte-americanas e europeias, formatando um modelo "à brasileira".

Outra influência para a confecção da primeira lei do ensino agrícola no Brasil veio do estado de São Paulo, tendo em vista que em relatório do MIVOP de 1909, o então ministro Miguel Calmon do Pin e Almeida ressaltava a estrutura e o orçamento destinado por aquele estado aos serviços agronômicos.

O estado de São Paulo vai sentindo em sua vida econômica a influência imediata da organização do ensino profissional. Arguido de exclusivista quando a maior soma de sua atividade, dos seus recursos se concentrava na cultura do café, pode hoje disputar primazia com os estados que se reputam melhor encaminhados no modo de aproveitar a uberdade de seu solo e o valor dos seus agentes de trabalho, e em breve tempo será incluído, pela variedade de sua produção, entre os melhores centros de policultura que possuímos (BRASIL-RMIVOP, 1909, p. 43). 
Um dos motivos indicados no relatório para o desenvolvimento paulista em termos de agricultura era a preparação de sua mão de obra através de vinte e oito estabelecimentos de instrução agrícola que se espalhavam por diversas cidades do estado. Desta forma, contava o estado paulista com um curso de engenharia agronômica ministrado na Escola Politécnica; uma Escola Agrícola Prática; dois Aprendizados Agrícolas; um Instituto Agronômico; uma Escola de Trabalhadores Rurais; uma Escola de Pomologia e Horticultura; uma Fazenda-Modelo; uma cultura de arroz por irrigação; uma Colônia Agrícola; quatro campos experimentais; quatro Hortos e dez Postos Zootécnicos.

O próprio modelo paulista de instrução agrícola já demonstrava o que viria ser a marca do ensino implantado em âmbito federal, com a incorporação de modelos estrangeiros, inclusive contando com a importação de mão de obra especializada. A maior parcela desses especialistas vinha da Europa, tais como Roberto Hottinger (médico veterinário pela Universidade de Zurich), que lecionou na Escola Politécnica; Joan Michel, Jacques Arié e J.J.Arthaut-Berthet, todos engenheiros agrônomos franceses, professores da Escola Agrícola Prática Luiz de Queiróz, e Hector Raquet, médico veterinário belga, formado pela Escola de Gembloux e que foi fundador do Posto Zootécnico Central (BRASIL-RMIVOP, 1909).

Entretanto, a pesquisadora Sônia Regina de Mendonça (1992) destaca a participação norte-americana na implantação do ensino agrícola paulista, especialmente na Escola de Piracicaba, e o assentamento de um novo paradigma para a agricultura:

[...] na ausência de quadros especializados recorreu-se, de imediato, a profissionais norte-americanos [...]. Clayton Smith, graduado por Cornell, seria o pioneiro na implantação do modelo americano de ensino agronômico em Piracicaba, marcado por seu cunho notadamente prático e voltado para os procedimentos da dita agricultura mecânica (MENDONÇA, 1992, p. 33).

Além de São Paulo, outro estado em que a presença de agrônomos norte-americanos causou grande influência nos destinos do ensino agrícola foi Minas Gerais, onde, em 1908, um grupo de presbiterianos fundou a Escola Superior de Agricultura de Lavras, tendo à frente o agrônomo Benjamin Hunnicut, formado pelo Mississipi State College.

Portanto, na constituição da primeira lei de ensino agrícola brasileira estavam presentes os modelos europeu, norte-americano e a forma como estes já haviam sido incorporados por São Paulo. Não quero dizer que a lei $\mathrm{n}^{\mathbf{0}} 8.319$, de 1910, foi uma incorporação de valores europeus e norte-americanos a partir de São Paulo, mas sim que a experiência paulista foi significativa para a formatação dessa lei.

O ministro Rodolpho Miranda em relatório do ano de 1910, explicando os motivos para a confecção da lei $\mathrm{n}^{\circ} 8.319$, apontava para a necessidade de se criar estabelecimentos de ensino agrícola que atendessem às demandas provenientes do campo e contemplassem uma das prerrogativas quando da criação do MAIC, que era a difusão deste tipo de ensino em todo o país, tendo em vista a escassez de estabelecimentos desta natureza:

[...] instalado o Ministério, restavam apenas das diversas instituições criadas em diferentes períodos, as de São Paulo que representam a organização mais completa do país, e os institutos de ensino agronômico do Rio Grande do Sul, Minas, Espírito Santo, Bahia e Pará, contando-se entre eles alguns recentemente instalados (BRASIL-RMAIC, 1910). 
No mesmo relatório, ressaltava o ministro que urgia a necessidade do governo federal de estabelecer um "plano harmônico" que buscasse a "unidade de ensino". Desta forma, asseverava que havia criado a instrução técnica profissional voltada para a agricultura, a qual compreendia o ensino agrícola de zootecnia, medicina veterinária e de indústrias rurais.

O decreto de criação do ensino agrícola contava com 591 artigos distribuídos em 65 capítulos. De acordo com o artigo $2^{\circ}$, do decreto $\mathrm{n}^{\circ} 8.319$, de 20 de outubro de 1910, o ensino agrícola teria as seguintes divisões: ensino superior, ensino médio ou teóricoprático, ensino prático, Aprendizados Agrícolas, ensino primário agrícola, escolas especiais de agricultura, escolas domésticas agrícolas, cursos ambulantes, cursos conexos com o ensino agrícola, consultas agrícolas e conferências agrícolas (BRASIL. Decreto $\mathrm{n}^{\circ}$ 8.319, 1910).

$\mathrm{O}$ ensino deveria ser ministrado em estabelecimentos adequados às finalidades indicadas para cada um; e atendendo ao seu caráter experimental, deveria ter como serviços e instalações complementares as estações experimentais, campos de experiência e demonstração, fazendas experimentais, estação de ensaio de máquinas agrícolas, postos zootécnicos e postos meteorológicos (IDEM).

No tocante ao ensino superior agrícola, este contava com 130 artigos, distribuídos em 10 capítulos, em que foi abordada a organização geral; a estrutura administrativa; a composição dos membros do magistério; a forma como se dariam o provimento nos cargos; a estrutura da congregação; os auxiliares de ensino; o regime escolar; a inscrição de matrícula; o método de ensino, os exercícios escolares e os exames; o curso de especialização de engenheiros agrônomos e os diplomas e prêmios de viagem.

O ensino agrícola superior seria ministrado na Escola Superior de Agricultura e Medicina Veterinária (ESAMV), que a partir de então serviria de modelo para o restante do país. A escola oferecia dois cursos, o de formação de engenheiros agrônomos e o de médicos veterinários, cada um deles dividido em fundamental e especial.

O curso fundamental de engenheiro agrônomo era realizado em um ano, dispondo de cinco Cadeiras e uma aula. Quanto ao curso especial, este era realizado em três anos, possuindo quinze Cadeiras e três aulas, distribuídas ao longo de cada ano. A formatação dada ao curso fundamental de engenheiro agrônomo era idêntica à do fundamental de medicina veterinária; entretanto, no tocante ao curso especial, havia uma grande diferença, visto que o de medicina veterinária era realizado em quatro anos, sendo composto por dezesseis Cadeiras e nenhuma aula (IBIDEM).

Em relatório apresentado ao presidente da república, o ministro Rodolpho Miranda ressaltava a importância da criação da ESAMV como importante instrumento para se formar professores e técnicos a fim de ocuparem postos na burocracia estatal:

Devendo ser a Escola Superior de Agricultura e Medicina Veterinária um viveiro de professores, de chefes de serviços técnicos, quer para os estabelecimentos do Governo, quer para a propriedade agrícola, entendo que se lhe deve dar organização adequada aos seus fins, não só provendoa de pessoal de ensino em número suficiente e de alta capacidade científica e experimental, senão do material indispensável, pois se a teoria professada nas cadeiras não for seguida da prática dos laboratórios, na fazenda experimental e mais dependências, serão infrutíferos os sacrifícios do Tesouro (BRASIL-RMAIC, 1910, p. 62). 
Buscando uma melhor formação dos engenheiros agrônomos, era pedido que o ministério criasse na ESAMV uma variedade de laboratórios e instalações que subsidiassem os trabalhos práticos dos alunos e as investigações científicas dos docentes. Para tanto, seria necessária a construção de, por exemplo, gabinete de física experimental, meteorologia e climatologia; laboratório de botânica e fisiologia vegetal-herbário; laboratório de química geral inorgânica; laboratório de zoologia - coleções didáticas; gabinete de mecânica geral, dentre outros espaços onde os alunos pudessem desenvolver suas pesquisas experimentais.

No entanto, apesar de disposta em lei a imediata criação da ESAMV, isto somente veio a ocorrer em 1913 devido à falta de um local apropriado e à escassez de verbas, promovida por um boicote da bancada paulista e de seus apoiadores que temiam a tomada da hegemonia, no tocante ao ensino superior agrícola, mantida pela Escola Superior de Agricultura Luiz de Queiróz (ESALQ) até aquele momento (MENDONÇA, 1998). Isto fez com que a ESAMV mudasse de sede várias vezes nos primeiros anos de sua existência e que seu primeiro corpo docente fosse formado apenas em 1913, quando era dirigido pelo agrônomo Gustavo D’Utra.

\section{QUADRO 2 - DOCENTES DA ESAMV 1913}

\begin{tabular}{|c|c|c|c|}
\hline $\mathrm{N}^{\mathrm{o}}$ & \multicolumn{2}{|r|}{ Docente } & Atribuições \\
\hline \multirow{2}{*}{1} & Lente & Arthur do Prado & \multirow{2}{*}{$\begin{array}{l}1^{\text {a }} \text { cadeira - Física experimental, meteorologia } \\
\text { e climatologia. }\end{array}$} \\
\hline & Substituto & Pedro Barreto Galvão & \\
\hline \multirow{2}{*}{2} & Lente & José de Freitas Machado & \multirow{2}{*}{$\begin{array}{l}2^{\mathrm{a}} \text { cadeira - química geral inorgânica e análise } \\
\text { química. }\end{array}$} \\
\hline & Substituto & Pedro Augusto Pinto & \\
\hline \multirow{2}{*}{3} & Lente & Graciano dos Santos Neves & \multirow{2}{*}{$\begin{array}{l}3^{\text {a }} \text { cadeira - botânica, morfologia e fisiologia } \\
\text { vegetal. }\end{array}$} \\
\hline & Substituto & Ezequiel Cândido de S. Britto & \\
\hline \multirow{2}{*}{4} & Lente & Cândido Firmino de M. Leitão Jr. & \multirow{2}{*}{$4^{\mathrm{a}}$ cadeira - zoologia geral e sistemática. } \\
\hline & Substituto & Gustavo Eduardo Hasselmann & \\
\hline \multirow[t]{2}{*}{5} & Lente & Renato Guimarães de S. Lopes & \multirow{2}{*}{$\begin{array}{l}5^{\mathrm{a}} \text { cadeira do curso fundamental de médico } \\
\text { veterinário e } 1^{\mathrm{a}} \text { cadeira do } 1^{\mathrm{o}} \text { ano do curso } \\
\text { especial de engenheiro agrônomo }- \text { química } \\
\text { orgânica e biologia. }\end{array}$} \\
\hline & Substituto & Othon Drumond F. de Mendonça & \\
\hline 6 & $\begin{array}{l}\text { Lente } \\
\text { (interino) }\end{array}$ & Sebastião Sodré da Gama & $\begin{array}{l}5^{\mathrm{a}} \text { cadeira do curso fundamental e } 5^{\mathrm{a}} \text { do } 1^{\mathrm{o}} \text { ano } \\
\text { do curso especial de engenheiro agrônomo - } \\
\text { noções de geometria analítica e mecânica geral, } \\
\text { topografia e estradas, estradas de rodagem e } \\
\text { caminhos vicinais. }\end{array}$ \\
\hline 7 & Professor & Thomaz Cavalcanti de Gusmão & $\begin{array}{l}\text { Aula de desenho a mão livre e geométrico, de } \\
\text { aquarela e topográfico. }\end{array}$ \\
\hline
\end{tabular}

Fonte: BRASIL. Relatório do Ministério da Agricultura, Indústria e Comércio. Rio de Janeiro: Imprensa Nacional, 1913.

Todos esses professores deveriam, segundo o regulamento, em suas aulas teóricas adotar o modo intuitivo, acrescido de excursões e trabalhos práticos em laboratórios e demais instalações de cada um dos cursos. Deveriam estimular o desenvolvimento do espírito de iniciativa dos alunos, fazendo com que estes manipulassem os objetos, as máquinas, ou seja, aprendendo através de sua própria experiência.

Esse método de ensino, preconizado para o ensino superior agrícola, guardava estreita relação com a pedagogia ativa desenvolvida nos Estados Unidos da América por John Dewey e que tinha sua base conceitual fundada no Pragmatismo, corrente filosófica norte-americana que teve como seu principal idealizador, Charles Sanders Peirce. A 
pesquisadora Patricia Turrisi, ao analisar a influência do Pragmatismo de Peirce para a educação, atenta para a importância da exposição à experiência:

Exposição à experiência (ou imersão nela) produz uma intimidade com o fenômeno que os estudantes buscam compreender, portanto uma imediatez a suas tentativas de se tornarem inteirados sobre as estruturas e os padrões da natureza. Experiências em laboratório ou de campo em ciências naturais, imersão em culturas em ciência social e línguas, e exposição a artefatos em história e arqueologia são exemplos de ricas fontes de experiência de onde derivam palpites originais sobre a natureza das coisas, e para compreender como outros podem ter derivado seus próprios palpites em circunstâncias similares (TURRISI, 2002, p. 130)

Essa ideia do aprender fazendo através do contato com as coisas deveria ser uma tônica na formação dos futuros engenheiros agrônomos e médicos veterinários; e, inclusive, nas férias, o regulamento previa a execução de exercícios práticos em estabelecimentos agrícolas, industriais ou em qualquer outro estabelecimento científico vinculado ao MAIC. Outro ponto que evidenciava a vertente pragmática dada ao ensino era a disposição legal que previa em seu artigo 112 que a prova prática precederia a teórica e teria uma natureza eliminatória (BRASIL. Decreto 8.319, de 1910).

Sobre o modelo adotado no ensino agrícola superior, que se materializava na ESAMV, Mendonça (1998) faz a seguinte colocação:

Enquanto uma escola de gestão, o 'aprender fazendo', era fundamental na determinação do ethos dos 'esamvianos', cujo destino último seria o alto e médio escalão da burocracia estatal e não a sua própria fazenda. Nesse sentido, saber fazer não implica apenas em 'saber mandar', mas sim, em 'saber obedecer' e, sobretudo, 'saber executar' (MENDONÇA, 1998, p. 145).

Outro elemento presente no ensino superior agrícola, que merece destaque, eram os prêmios e viagens concedidos àqueles alunos que se destacavam ao longo do curso. Este procedimento enfatizava a competitividade entre os alunos, uma das marcas da sociedade capitalista, de modo que os que se destacassem poderiam ascender a uma das cadeiras de substituto na ESAMV sem a necessidade de concurso e, ainda, poderiam ganhar uma viagem para aprofundar seus estudos em outros países.

Entre os artigos 135 e 218, o decreto $\mathrm{n}^{\circ} 8.319$ versava, ao longo de dez capítulos, sobre o ensino agrícola médio ou teórico-prático, aludindo a seus objetivos, sua organização, estrutura física e equipamentos, administração e corpo docente, auxiliares de ensino, regime escolar, inscrição e matrícula, método de ensino, exames, diplomas e premiações.

No tocante aos objetivos, as escolas médias deveriam ter um caráter regional, dedicando-se às culturas e às indústrias rurais de sua localidade, contribuindo, desta forma, para o desenvolvimento econômico da região. Para tanto, seria destinado um curso de três anos divididos em semestres e, ao final, um ano de estágio.

Além do curso regular, as escolas médias ou teórico-práticas, deveriam ofertar cursos resumidos, voltados para os agricultores, criadores ou industriais que quisessem se especializar em um ou mais ramos relacionados às suas atividades.

Ainda com relação ao ensino médio ou teórico-prático, percebe-se outra marca do modelo de ensino agrícola brasileiro: a tentativa de integrar os diferentes estabelecimentos 
de ensino agrícola, favorecendo a administração e contribuindo com a formação prestada. Desta forma, a pesquisadora Maria da Glória de Rosa (1980) chama atenção para a possibilidade de integrar vários estabelecimentos em um só espaço:

As essas escolas médias poderiam ser anexados, além da fazenda experimental, posto zootécnico ou estação agronômica. E aos cursos por ela ministrados facultar-se-ia também a anexação de aprendizados agrícolas, sob a forma de internato ou externato (ROSA, 1980, p. 71).

Essa possibilidade de integração estava presente também em outras instituições de ensino, a exemplo dos Aprendizados Agrícolas, como será abordado e debatido em capítulo posterior.

O método de ensino a ser adotado nas escolas médias deveria ser semelhante ao disposto para a Escola Superior de Agricultura e Medicina Veterinária, sendo, no entanto, de menor complexidade. Para subsidiar o ensino oferecido, as escolas médias ou téoricopráticas deveriam dispor dos seguintes laboratórios e instalações: gabinete de física; posto meteorológico; laboratório de botânica, zoologia e patologia vegetal; gabinete de topografia e desenho; laboratório e gabinete de química mineral - mineralogia e geologia; laboratório de química orgânica, química agrícola e bromatológica e tecnologia industrial agrícola; gabinete de engenharia rural; galeria de máquinas; gabinete de zootecnia; farmácia veterinária; hospitais veterinários e anexos; fazenda experimental; museu agrícola e de história natural; bibliotecas; oficinas para o trabalho do ferro e da madeira.

Para a direção dos estabelecimentos das escolas médias ou teórico-práticas requeriase a formação de engenheiro agrônomo e, os lentes das instituições seriam escolhidos através de concurso, o mesmo que era previsto no ensino superior agrícola. Quanto ao corpo discente, exigia-se a idade mínima de 17 e a máxima de 21 anos, e ao final do curso os concluintes receberiam o título de agrônomos (ROSA, 1980).

Os alunos que se destacassem teriam prioridade na ocupação de espaços na máquina estatal ligada ao âmbito de sua formação. Poderiam, ainda, adentrar escolas médias para ocupar o posto de professor, além de receber como prêmio viagens para aprofundamento dos estudos em outros países.

Em 1913, o relatório do MAIC anunciava que estavam em funcionamento apenas três estabelecimentos de ensino médio agrícola: a Escola de Agricultura de Pinheiro, que funcionava anexa ao Posto Zootécnico Federal, situado no estado do Rio de Janeiro; a Escola Agrícola da Bahia, que funcionava em São Bento de Lages e possuía uma fazendamodelo anexa, e a Escola Média de Porto Alegre, que fazia parte das instituições de ensino agrícola da Escola de Engenharia (BRASIL-RMAIC, 1913).

Do artigo 219 ao 267, ao longo de cinco capítulos, a lei de ensino agrícola ressaltava o ensino prático de agricultura e, assim como os demais, referia-se aos objetivos, organização, método de ensino, estrutura, corpo discente, regime escolar, matrícula, prêmios e diplomas. Entretanto, percebe-se claramente que a importância atribuída a esse tipo de ensino não era a mesma conferida aos anteriores, isto se refletindo inclusive no espaço destinado na legislação.

Quanto às finalidades de ensino agrícola prático, expressava o decreto:

Art. 219. O ensino prático de agricultura será professado em escolas cujo objetivo consiste em formar chefes de cultura, administradores de propriedades rurais e instruir os filhos de agricultores e aqueles que se queiram dedicar à vida agrícola, nos modernos processos de cultura, e nas 
praticas referentes à zootecnia veterinária e indústrias rurais (BRASIL. Decreto $\mathrm{n}^{\circ} 8.319$ de 1910).

As escolas práticas de agricultura estavam voltadas para alunos que já tivessem concluído o ensino primário e que quisessem dedicar-se e adotar a "profissão" agrícola. $\mathrm{O}$ curso era de três anos, divididos em semestres, constando de trabalhos práticos, ensino profissional elementar e da ampliação e revisão do curso primário.

Quanto ao corpo docente, este seria escolhido através de concursos, privilegiando-se os engenheiros agrônomos, os agrônomos e aqueles que tivessem notória competência para tal, inclusive com artigos publicados sobre temas da área do concurso. O corpo discente seria formado por alunos entre 14 e 18 anos de idade, em regime de internato e externato.

O método de ensino a ser utilizado era idêntico ao previsto para as escolas médias e teórico-práticas, adequando-se ao nível de conhecimento dos alunos, tornando-se o mais prático e objetivo possível. O aluno que concluísse os três anos de estudos receberia o título de regente agrícola, tendo privilégio na admissão em órgãos vinculados ao MAIC e, ainda, podendo ocupar postos de trabalho nos Aprendizados Agrícolas e em escolas do mesmo nível de sua formação.

Dos artigos 268 ao 331, o Decreto $\mathrm{n}^{\circ} 8.319$ reportava-se aos Aprendizados Agrícolas, que, como objeto deste trabalho, merecerão atenção especial nos capítulos posteriores, no sentido de estudar de forma mais detida seus objetivos, estrutura, organização e regime escolar, corpo docente e discente e o método de ensino adotado.

O capítulo 27, em seus treze artigos, enfocava os objetivos e conteúdos prioritários a serem trabalhados nas aulas do ensino primário agrícola. Desta forma, determinava que o ensino primário agrícola fizesse parte dos programas das escolas primárias presentes nas escolas práticas de agricultura, nos aprendizados agrícolas, nos núcleos coloniais, nos centros agrícolas e em qualquer estabelecimento de ensino agronômico em que fosse necessária a sua utilização.

O objetivo desse tipo de ensino seria despertar o interesse dos alunos pela vida no campo, podendo ser realizado por ambos os sexos, adotando-se exclusivamente o método experimental para não "sobrecarregar a memória dos alunos" (BRASIL, Decreto no 8.319 de 1910). O ensino deveria levar em consideração o grau em que o aluno estivesse na gradação escolar, ou seja, elementar, médio ou superior.

Causa espanto a adoção da coeducação nessa modalidade de ensino, fato que já se observava nos Estados Unidos da América desde o século XIX, segundo ressalta o agrônomo Gustavo D’Utra em relatório entregue à Secretaria da Agricultura, Comércio e Obras Públicas de São Paulo, após sua viagem de estudos realizada àquele país:

A coeducação, no ensino agrícola, é outra singularidade no povo norteamericano.

Nos colégios de agricultura e nas universidades os alunos de ambos os sexos, moços que se matriculam com 15 anos de idade e moças que entram para os cursos com 17 anos, vivem a mesma vida acadêmica, são admitidos nas mesmas condições, seguem os mesmos cursos, têm os mesmos deveres e gozam os mesmos privilégios em todas as seções [...] (D’UTRA, 1908, p. 16-17).

No curso elementar, a legislação previa a adoção das lições de coisas com aplicações simples e intuitivas sobre os reinos da natureza, atentando-se para as transformações mais comuns ocorridas em função do trabalho agrícola e industrial. Para 
complementar este ensino, realizavam-se passeios, excursões e organização de pequenas coleções escolares.

A legislação ainda ressaltava que nas aulas de escrita, leitura, cálculo mental, exercícios de desenho e demais lições fosse dada a preferência a assuntos que se relacionassem à história natural e à agricultura.

Nos cursos médio e superior, o ensino primário agrícola devia adotar o mesmo método do curso elementar, ou seja, intuitivo e experimental, contando sempre que possível com o auxílio de equipamentos e com a realização de muitos exercícios e demonstração, levando-se em conta a capacidade dos alunos. A maior diferença entre o curso médio e o superior era que neste último seriam passadas as primeiras noções de física e química.

Como elementos complementares ao ensino primário agrícola, os alunos realizariam trabalhos manuais, ensino profissional elementar, desenho, datilografia, ginástica, jogos esportivos e exercícios militares, respeitando-se a capacidade física dos alunos (IDEM).

O capítulo 38 com seus nove artigos referia-se aos cursos especiais de agricultura, o qual se destinava ao estudo detalhado de certos ramos da agricultura que melhor atendessem ao desenvolvimento da cultura regional. Quanto ao regulamento, deveria ser seguido o que estava previsto para as escolas práticas.

As escolas especiais de agricultura deveriam destinar-se, principalmente, à horticultura, à fruticultura, às culturas forrageiras e a qualquer cultura industrial. No tocante às escolas práticas que se destinavam à horticultura e à fruticultura, previa o decreto:

Art. 350. As escolas práticas de horticultura e fruticultura compreenderão em seu programa, com maior desenvolvimento que nas escolas práticas, em geral, a arboricultura frutícola, a cultura e as construções hortícolas, a cultura florestal e de ornamento, a jardinocultura, floricultura, ornamentação floral, arquitetura paisagista, apicultura, sericicultura, avicultura e a criação de pequenos animais domésticos (BRASIL. Decreto $\mathrm{n}^{\mathrm{o}} 8.319$ de 1910).

Contudo, o relatório do MAIC de 1910 asseverava que a criação dessas escolas deveria ser deixada para o futuro, levando-se em consideração as condições orçamentárias da União, ressaltando, ainda, que no tocante às escolas práticas e aos aprendizados de horticultura e pomicultura seria necessária uma rápida difusão por todo o território nacional (BRASIL-RMAIC, 1910).

A lei do ensino agrícola não se esqueceu de uma educação agrícola voltada para a clientela feminina, para a qual em seu capítulo 39 versava sobre as escolas domésticas de agricultura. Nestas buscava-se preparar as filhas dos agricultores para a vida agrícola, ministrando-lhes o ensino que mais se adequasse ao sexo feminino.

O programa das escolas domésticas deveria revisar e ampliar o ensino primário, propiciando o aprendizado da leitura e da escrita para aquelas que ainda não soubessem. Concomitante a esta formação, deveria ser passado o ensino elementar de ciências acessórias, da horticultura, fruticultura, jardinocultura, floricultura, zootecnia, indústrias rurais, sobretudo a de laticínios e, ainda, a economia doméstica, economia social, noções de higiene geral, de direito usual, de comércio e contabilidade agrícola.

Os cursos ambulantes de agricultura foram lembrados no capítulo 40, dos artigos 359 ao 377. Estes cursos seriam destinados aos agricultores que por circunstâncias especiais encontravam-se impedidos de frequentar os cursos regulares de ensino agrícola. Os cursos deveriam compreender os diversos ramos da agricultura geral e especial e, também, zootécnica, alimentação e higiene dos animais domésticos, indústrias rurais, 
arboricultura frutícola, horticultura, moléstias comuns às plantas cultivadas, sericultura, apicultura, avicultura, dentre outras.

Para que um curso ambulante pudesse ser montado deveria ter no mínimo vinte interessados, tendo estes que assumir os custeios do deslocamento dos professores e o transporte do material didático. Os professores deveriam dispor de uma série de coleções didáticas de historia natural, instrumentos e aparelhos apropriados ao estudo elementar de ciências físico-químicas, um laboratório de química agrícola, pequeno laboratório portátil, amostras de terras, adubos, mapas relativos a máquinas agrícolas e aos diversos ramos de agricultura nacional, aparelhos portáteis para o fabrico de queijo e da manteiga, máquinas e utensílios para aplicação de inseticidas, fungicidas, etc (BRASIL. Decreto $\mathrm{n}^{\mathbf{0}} 8.319$ de 1910).

Aqueles alunos que quisessem receber um certificado de proficiência na matéria realizada nos cursos poderia submeter-se a um exame perante uma banca examinadora, que seria constituída pelo Inspetor Agrícola, pelo professor do curso ambulante e por um professor de escola de ensino agrícola, este a ser escolhido pelo ministro.

Os professores dos cursos ambulantes teriam a responsabilidade de distribuir resumos impressos de suas aulas para todos os participantes, indicando bibliografia para aqueles que quisessem aprofundar-se nos assuntos. Além desta atribuição, a legislação determinava mais dezenove responsabilidades aos docentes.

No $1^{\circ}$ Congresso de Ensino Agrícola realizado em São Paulo, no ano de 1911, um dos pontos debatidos foi o ensino nômade, que tinha o mesmo princípio dos cursos ambulantes. Na $6^{\mathrm{a}}$ tese defendida neste congresso, ressaltavam-se os benefícios dessa prática para o desenvolvimento e a vulgarização das modernas técnicas agrícolas:

Para o ensino nômade, nós levamos à chácara, ao sítio, à fazenda, as noticias que mais possam interessar ao agricultor; informamo-lo do que se passa nos modernos campos de experiência a respeito de certos produtos; aconselhamos certas culturas próprias da região que habita; mostramos a influência benéfica das matas e o perigo das derrubadas; apontamos os erros que se nos deparam e mostramos os meios de remediá-los e evitar a repetição de outros que cavam a sua ruína; levamos ao seu conhecimento os resultados conseguidos nos laboratórios, no estudo do solo e no preparo ou beneficiamento dos produtos; ensinamos-lhe o modo de combater e prevenir as pragas, e, enfim, de um modo cômodo para ele, instruímo-lo na sua própria fazenda (GRANATO, 1918, p. 39-40).

O ensino nômade e os cursos ambulantes seriam "duas faces de uma mesma moeda", ou seja, faziam parte de um projeto que visava à massificação do discurso científico, respaldado nas ciências agrícolas, como a única forma de se superar o "atraso" em que se encontrava o campo. E deveriam ser encontradas formas de se levar ao maior número de pessoas as ferramentas (técnicas) necessárias para que fosse adotado no Brasil o modelo de sucesso já aplicado em outros países.

O modelo de curso ambulante adotado no Brasil assemelhava-se ao norteamericano, tomando por base o relatório de viagem de Gustavo D'Utra, no qual enfatiza que nos EUA:

[...] não são os professores que se deslocam de um lugar para outro, fazendo preleções ou conferências, como se usa na Europa, não; é a escola, com todo o seu material de ensino e de demonstrações, que se transporta de um ponto para o outro. 
Em qualquer lugar que pareça conveniente, aí funciona ela. Até em um trem de estrada de ferro tem funcionado o ensino ambulante, de estação em estação. As lições duram dois ou três dias consecutivos, constando os programas, previamente organizados, de questões atuais, que interessem em alto grau aos agricultores (D'UTRA, 1908, p. 19).

Os cursos ambulantes, diferente, por exemplo, dos cursos práticos e das escolas domésticas, começaram a ser criados logo após a aprovação do decreto 8.319, tanto que em 1913 eles já se encontravam distribuídos em dezenove sedes, tendo cada um sua especialidade, como se pode ver no quadro a seguir:

\section{QUADRO 3 - CURSOS AMBULANTES CRIADOS ATÉ 1913}

\begin{tabular}{|c|c|c|c|}
\hline Estado & Sede & Professor & Especialidade \\
\hline \multirow{2}{*}{$\begin{array}{c}\text { Rio Grande } \\
\text { do Sul }\end{array}$} & Taquari & Emilio Schenk & Apicultura \\
\hline & Bento Gonçalves & Paul Pieron & Laticínios e Avicultura \\
\hline \multirow{5}{*}{$\begin{array}{c}\text { Santa } \\
\text { Catarina }\end{array}$} & São José & Alberto de Moraes Aguiar & Agricultura em Geral \\
\hline & Jaraguá & Manoel Ramos & Cultura do Fumo \\
\hline & Blumenau & Emílio Thamstem & Laticínios \\
\hline & Urussanga & Tullo Cavallazi & Viticultura e sericultura \\
\hline & Lages & Bruno Hanff & Agricultura geral, cereais e forragens \\
\hline Paraná & Curitiba & Alberto Falciola & Vinicultura, viticultura e pomicultura \\
\hline \multirow{2}{*}{$\begin{array}{l}\text { Rio de } \\
\text { Janeiro }\end{array}$} & Paraíba do Sul & Domingos Bernardes & Agricultura geral \\
\hline & Rezende & Arthur Gama de Avellar & Agricultura geral e laticínios \\
\hline $\begin{array}{l}\text { Distrito } \\
\text { Federal }\end{array}$ & Realengo & Dr. Philippe Aristides Caire & Horticultura, pomicultura e floricultura \\
\hline \multirow{5}{*}{$\begin{array}{l}\text { Minas } \\
\text { Gerais }\end{array}$} & Itajubá & Camillo Gomes de Souza & Agricultura geral \\
\hline & $\begin{array}{l}\text { São Gonçalo do } \\
\text { Sapucaí }\end{array}$ & Ormino Rodrigues Vidigal & Agricultura geral e laticínios \\
\hline & Leopoldina & Arthur da Cunha Barros & Agricultura geral e laticínios \\
\hline & Barbacena & $\begin{array}{l}\text { Paulo de Deus Moretzsohn } \\
\text { Monteiro de Barros }\end{array}$ & Laticínios \\
\hline & Curvelo & Bernardino de Campos Lima & Agricultura Geral \\
\hline $\begin{array}{l}\text { Espírito } \\
\text { Santo }\end{array}$ & Muqui & Oscar Ferreira Alves & Agricultura geral \\
\hline \multirow{2}{*}{ Bahia } & Areia & Lodonio Ferreira de Almeida & Agricultura Geral e Cultura do Fumo \\
\hline & Alta-Mira & Ubaldino Quirino de Bomfim & Agricultura Geral \\
\hline
\end{tabular}

Fonte: BRASIL. Relatório do Ministério da Agricultura, Indústria e Comércio. Rio de Janeiro: Imprensa Nacional, 1913.

Esses cursos, no entanto, não tiveram grande duração, de tal forma que a partir de 1915 não é possível mais encontrarem-se referências sobre a realização destes nos relatórios do Ministério da Agricultura, Indústria e Comércio.

Os capítulos 41, 42 e 43, reportam-se, respectivamente, aos cursos conexos, às consultas agrícolas e às conferências agrícolas. No que diz respeito aos cursos conexos, a legislação previa que o de História Natural promovido pelo Museu Nacional guardaria relação com os do ensino agrícola superior, ressaltando-se que outros cursos criados na mesma condição deste gozariam da mesma prerrogativa.

Com relação às consultas agrícolas, deveria o ministro expedir instruções para regulamentar tal serviço; no entanto estava posto que qualquer estabelecimento de ensino agrícola ou estabelecimento ligado ao MAIC teria a obrigação de responder às consultas 
que lhe fossem dirigidas pelos seus respectivos diretores, pelos agricultores, criadores e pelos profissionais da indústria rural.

Por último, aborda as conferências agrícolas que, segundo a legislação, ficariam a cargo dos inspetores agrícolas e seus ajudantes. Estas ainda poderiam ficar sob a responsabilidade dos professores dos cursos ambulantes, porém neste caso deveria versar sobre tema específico, sendo precedidas de demonstrações. As conferências teriam como uma das suas principais finalidades a propaganda em favor das associações agrícolas, principalmente da Sociedade Nacional de Agricultura, e da difusão dos princípios gerais correlacionados às atividades rurais (BRASIL-RMAIC, 1910-1917).

Os capítulos 44 e 45 e seus vinte e um artigos versavam sobre as instalações complementares do ensino agrícola. O capítulo 44 tratava especificamente das estações experimentais, ressaltando como seu principal objetivo o estudo experimental de todos os fatores relacionados à produção agrícola regional, proporcionando aos agricultores dados precisos para o aperfeiçoamento e melhor rendimento de suas culturas.

Para corresponder aos objetivos de sua criação, as estações experimentais deveriam contemplar quatorze pontos: consultas que lhes forem feitas sobre qualquer questão agrícola de sua competência; executar gratuitamente análises de estrumes, adubos, terras, plantas e águas; distribuir plantas e sementes selecionadas; promover o melhoramento dos processos concernentes à bonificação dos produtos agrícolas e às indústrias agrícolas; realizar experimentações e culturas de plantas úteis, compreendendo as que forem comuns à região e outras que devam ser nela exploradas, assim como todos os trabalhos referentes ao melhoramento dos terrenos; estudar as moléstias comuns às plantas cultivadas, os meios de combatê-las, vulgarizando-os entre os interessados; proceder ao estudo agrológico e químico das terras, quer para as necessidades imediatas da cultura regional, quer para organização da carta agrológica; estudar a composição química dos estrumes, adubos, corretivos, águas, alimentos de origem vegetal e animal; fazer experiências sobre alimentação dos animais domésticos; estudar de forma prática o aproveitamento industrial dos produtos agrícolas, o fabrico do queijo, da manteiga, por exemplo, caso a estação funcionasse em zona pastoril; proceder a estudos sobre fermentos, fermentações, destilação, conforme os interesses econômicos e industriais da região; promover o desenvolvimento da policultura; concorrer para o aperfeiçoamento de uma cultura determinada, estudando-a sob o ponto de vista cultural e da bonificação, métodos de conservação, embalagem e comércio dos respectivos produtos; contribuir para a especialização dos alunos que concluíssem o curso da Escola Superior de Agricultura e Veterinária do Brasil, das escolas médias ou teórico-práticas e para a instrução técnica de qualquer profissional de agricultura ou de indústria rural (BRASIL. Decreto 8.319 de 1910).

As estações experimentais deveriam ter em sua organização três divisões responsáveis pelo desenvolvimento dos trabalhos técnicos: laboratório de biologia vegetal, laboratório de química e seção agronômica. Os trabalhos desenvolvidos nas estações e que pudessem contribuir com o desenvolvimento da agricultura e das indústrias rurais deveriam fazer parte de um periódico a ser distribuído gratuitamente.

O auge da criação das estações experimentais ocorreu ao final da década de 1930, com a reformulação do Ministério da Agricultura e a criação, como órgão vinculado a este ministério, do Centro Nacional de Ensino e Pesquisas Agronômicas (CNEPA), o qual será abordado no último capítulo. Neste momento chegaram a existir vinte e uma estações experimentais espalhadas por diversas regiões, especializando-se, como propunha o regulamento, no desenvolvimento das culturas locais (BRASIL-RMA, 1942). 
Outros elementos constituintes e promotores do ensino agrícola eram os campos de experimentação e de demonstração, os quais estavam referenciados no decreto 8.319, do artigo 404 ao 427, englobando os capítulos 46 e 47. Os campos de experimentação deveriam ser criados nas escolas de ensino médio e superior agrícola, bem como nas estações experimentais, servindo apenas para ensaios e estudos. Tais espaços deveriam ser dirigidos por engenheiros-agrônomos ou agrônomos, tendo ao seu dispor um laboratório de química agrícola e vegetal.

As pesquisas desenvolvidas nos campos de experimentação somente poderiam ser vulgarizadas quando pudessem servir de ensinamento aos agricultores locais. Desta forma, contribuíram sobremaneira os campos de demonstração, visto que estes espaços deveriam ser divididos, ressaltando-se o trabalho de cultivo em decorrência da pesquisa realizada e aquilo que vinha sendo realizado pelos agricultores da região, para que assim ficassem mais evidentes os benefícios da adoção de novas técnicas.

Outro elemento acessório do ensino agrícola eram as fazendas experimentais, que seriam destinadas ao ensino prático da agricultura, em seus diferentes ramos, por meio de demonstrações e culturas sistemáticas das plantas úteis, principalmente das que fossem comuns à região em que se achavam estabelecidas, contando com o auxílio de práticas referentes à zootecnia e às indústrias rurais (BRASIL. Decreto 8.319 de 1910).

As fazendas experimentais deveriam ser criadas anexas a todos os tipos existentes de estabelecimento de ensino agrícola, devendo atender aos princípios da pequena, média e grande agricultura, dispondo, para tanto, das divisões de agricultura, zootecnia e indústrias rurais. $\mathrm{O}$ tamanho destinado à fazenda experimental variava a depender do tipo de escola de ensino agrícola à qual se encontrasse anexa. Desta forma, para a Escola Superior de Agricultura e Medicina Veterinária a área deveria ser de 100 hectares; para as escolas médias ou teórico-práticas, 50 hectares; para as escolas práticas, 30 hectares, e 20 hectares para os Aprendizados Agrícolas e campos de experiências ou demonstrações.

Ainda reportando-se aos serviços complementares do ensino agrícola, o capítulo 49 do decreto $\mathrm{n}^{\circ} 8.319$ trazia as estações de ensaio de máquinas, as quais teriam a responsabilidade de avaliar, por meio de estudos e experimentação, a quantidade e qualidade dos trabalhos desenvolvidos pelas máquinas agrícolas e de indústria rural.

As estações de ensaio de máquinas deveriam manter um serviço gratuito de orientação aos agricultores, divulgando o preço das máquinas agrícolas e das indústrias rurais e indicando aquelas que seriam mais apropriadas ao tipo de trabalho a ser realizado. As estações deveriam dispor em sua estrutura de uma estação de desenho para detalhamento gráfico dos equipamentos testados e de um ateliê fotográfico para registro dos tipos existentes de máquinas agrícolas e das indústrias rurais.

Apesar de, no início do capítulo, a legislação apontar para uma generalização desses organismos por todos os estabelecimentos de ensino agrícola, no artigo 448 especifica-se que caberia ao governo federal a criação de uma estação de ensaios de máquinas apenas na Escola Superior de Agricultura e Medicina Veterinária, ficando como uma possibilidade a criação destas unidades em outras instituições.

Os capítulos 50, 51 e 52 referem-se, respectivamente, aos postos zootécnicos, aos postos meteorológicos e ao ensino de zootecnia. Começando pelo terceiro (ensino de zootecnia), este deveria ser ministrado em cadeiras especiais nos estabelecimentos de ensino agrícola, nos postos zootécnicos, nos postos de seleção do gado animal, nas estações zootécnicas regionais, nas coudelarias ${ }^{7}$, em escolas especiais da indústria rural e nas escolas de laticínios. 
No caso dos postos meteorológicos, estes deveriam ser criados em todos os estabelecimentos de ensino agrícola ou instituições conexas, guardando em sua organização e regulamento as instruções da Diretoria de Meteorologia e Astronomia.

Por último, estavam os postos zootécnicos, que tinham por finalidade desenvolver a indústria da pecuária e outras correlatas. Para tanto, tinham vinte atribuições que passavam pelo ensino, pesquisa, extensão, inspeção pecuária, divulgação científica e organização de eventos.

No tocante ao ensino, uma das atribuições era ministrar aos criadores noções de higiene e alimentação dos animais. Quanto à pesquisa, um exemplo era o estudo das moléstias e parasitas que afetavam o gado, recomendando a profilaxia e o tratamento. Como prática de extensão, os postos zootécnicos tinham a responsabilidade de fornecer reprodutores que propiciassem o melhoramento da genética dos animais dos produtores da região.

A inspeção pecuária era evidenciada na interferência, na importação de reprodutores para os pecuaristas e no registro genealógico dos animais existentes na região. A divulgação científica era realizada através da expedição de boletins ou publicações avulsas sobre as pesquisas desenvolvidas no estabelecimento. Por fim, a organização de eventos, que deveria ser realizada com a orientação e direção de concursos e exposições.

Para o desenvolvimento de tais tarefas, os postos zootécnicos deveriam contar com três seções: Zootecnia e Veterinária, Agrostologia ${ }^{8}$ e Bromatologia ${ }^{9}$, Laticínios. Visando ao bom funcionamento de cada uma destas seções, os postos zootécnicos deveriam dispor de uma estrutura com: gabinete de zootecnia, com esqueletos, preparações anatômicas, modelos para estudo da anatomia e fisiologia; laboratório de bacteriologia, farmácia veterinária, hospital veterinário, sala de autópsias, banheiros, policlínica; laboratório de química agrícola e bromatologia; fazenda experimental, com campos de experiência e demonstração; campos de cultura; instalação para indústria de lacticínios, com laboratório; biblioteca e posto meteorológico.

Cada seção dos postos zootécnicos seria responsável pela condução de cursos que tinham estruturas e objetivos diferenciados, como se pode perceber no quadro a seguir: 


\section{QUADRO 4 - CURSOS MINISTRADOS NOS POSTOS ZOOTÉCNICOS}

\begin{tabular}{|c|l|}
\hline Curso & \multicolumn{1}{c|}{ Formação } \\
\hline $\begin{array}{c}\text { Curso teórico de } \\
\text { zootecnia }\end{array}$ & $\begin{array}{l}\text { Noções elementares sobre o exterior dos animais domésticos, suas } \\
\text { diferentes raças, reprodução, criação, higiene, alimentação e cuidados } \\
\text { que lhes devem ser dispensados e prática de medicina veterinária. }\end{array}$ \\
\hline $\begin{array}{c}\text { Curso de } \\
\text { Agrostologia }\end{array}$ & $\begin{array}{l}\text { Noçães elementares sobre o solo, clima, prados naturais e artificiais, } \\
\text { irrigação e drenagem, forragens nacionais e estrangeiras, seu valor } \\
\text { nutritivo, produção racional, métodos de conservação e prática de } \\
\text { contabilidade. }\end{array}$ \\
\hline $\begin{array}{c}\text { Curso teórico de } \\
\text { lacticínios e de } \\
\text { fabrico de queijo }\end{array}$ & $\begin{array}{l}\text { Conhecimentos elementares sobre composição do leite, alterações, } \\
\text { falsificação e meios de verificá-las, instalações de leiterias, venda, } \\
\text { transporte do leite, fabricação do queijo e da manteiga. }\end{array}$ \\
\hline
\end{tabular}

Fonte: BRASIL. Decreto n ${ }^{\circ} 8.319$, de 20 de outubro de 1910.

Os postos zootécnicos deveriam contar, também, com cursos abreviados que demorariam entre dois e três meses. Para efetuar a inscrição nestes cursos, o pleiteante deveria comprovar ter idade superior a 14 anos; exibir certificado de instrução primária e declarar estar apto para desenvolver todos os trabalhos práticos condizentes com a sua idade e aptidão física.

Os postos zootécnicos poderiam incorporar, ainda, os postos de seleção do gado nacional, que poderiam ser criados também independentemente dos primeiros em regiões onde fossem necessários seus serviços.

Além de poder incorporar os postos de seleção de gado, os postos zootécnicos estimulariam o desenvolvimento da agropecuária através do gerenciamento das estações zootécnicas, criadas pelos estados e subvencionadas pela União. Para a criação das estações zootécnicas, os governos estaduais ou associações deveriam doar um terreno apropriado em que a União se encarregaria de colocar reprodutores, assim como animais de trabalho, instrumentos agrícolas, sementes, plantas, adubos, dentre outros elementos que pudessem subsidiar os produtores locais.

Outro estabelecimento que poderia funcionar anexo aos postos zootécnicos, ou independente destes, eram as coudelarias. Estas teriam por objetivo a criação e multiplicação de reprodutores visando ao desenvolvimento da raça cavalar no país.

A criação das coudelarias tem uma inspiração francesa, visto que a França contava com uma Escola Nacional de Coudelarias desde meados do século XIX, onde o aluno aprenderia

[...] a ciência hípica - influência que modifica as raças; geografia hípica; genealogia; modos de reprodução; leis da hereditariedade; modos de criação; cursos ou carreiras; instruções hípicas do país; administração e manutenção dos estabelecimentos; contabilidade e noções de direito administrativo; equitação teórica e prática; emparelhamento e endireitamento; agricultura teórica e prática; botânica forrageira; higiene; anatomia fisiologia; exterior do cavalo; medicina veterinária; ferração; desenho e inglês (D’UTRA, 1908, p. 207-208).

No caso brasileiro, as coudelarias teriam duas divisões: a de zootecnia e veterinária e outra dedicada à cultura das plantas forrageiras, seu beneficiamento, conservação e embalagem. Um dos motivos que levaram à inserção das coudelarias na primeira lei do ensino agrícola brasileiro talvez estivesse relacionado ao fato de que desde os novecentos, principalmente na cidade do Rio de Janeiro, o turfe era o principal esporte praticado, Revista HISTEDBR On-line, Campinas, $n^{o}$ 63, p. 64-88, jun2015 - ISSN: 1676-2584 
configurando-se os hipódromos como locais de grande aglomeração popular (MELO, 2001). Desta forma, era importante o desenvolvimento da raça equina nacional.

No relatório ministerial de 1910, o ministro Rodolpho Miranda atentava para a importância dos serviços complementares ao ensino agrícola, como elemento essencial para a eficácia do ensino agrícola e aproveitamento racional dos agentes de produção agrícola. Deste modo, asseverava o ministro:

As estações e fazendas experimentais, os campos de experiência e demonstração, a estação de ensino de máquinas que será anexada à Escola Superior de Agricultura e Medicina Veterinária, os postos zootécnicos e os postos meteorológicos, estão de tal modo ligados com o plano geral do ensino que a eliminação de qualquer desses serviços o perturbaria fundamentalmente, fazendo perigar sua execução (BRASIL-RMAIC, 1910, p. 63-64).

O capítulo 63 do decreto de criação do ensino agrícola versava sobre o ensino voltado para as indústrias rurais. No primeiro artigo referente a este tópico, esclarecia os locais e as finalidades desse ensino:

Art. 500. O ensino das indústrias rurais será professado em escolas especiais, cursos ambulantes e em escolas de lacticínios, e tem por fim difundir a instrução profissional, atinente à tecnologia industrial agrícola, preparando pessoal apto para a direção dos estabelecimentos de indústria rural e colaboradores educados na prática racional dos diferentes serviços (BRASIL. Decreto n ${ }^{\circ} 8.319$ de 1910).

Para tanto, os cursos das escolas especiais de indústrias rurais teriam um programa similar ao das escolas práticas, compreendendo em sua parte teórica o ensino de matemática elementar, noções de história natural e físico-química, noções de desenho, mecânica, desenho de construções e de máquinas, noções de agricultura, zootecnia, veterinária, tecnologia industrial agrícola, microbiologia, economia rural e contabilidade. Tal programa poderia desenvolver-se no atendimento de uma especialidade, de forma a atender aos reclamos locais, a exemplo das indústrias de laticínios.

A parte final do decreto $\mathrm{n}^{\circ} 8.319$ diz respeito às escolas de laticínios, dividindo-se em escolas permanentes e escolas temporárias. Quanto às escolas permanentes, estas compreenderiam as manipulações relativas ao leite, manteiga e ao queijo, abrangendo também a criação dos animais, alimentação, higiene, tratamento, até o fabrico desses produtos, sua embalagem, transporte e comércio (IDEM).

O regime escolar desses estabelecimentos deveria ser igual ao dos Aprendizados Agrícolas, dividindo o tempo escolar entre trabalhos práticos, lições relativas ao curso primário ou elementar de química, análise do leite, zootécnica, fermentos e fermentação. $\mathrm{O}$ tempo de duração dos cursos seria de dois anos, funcionando em regime de externato, recebendo alunos de ambos os sexos ou exclusivamente do sexo feminino.

As escolas de laticínios permanentes, assim como as coudelarias, parecem ter uma influência da organização do ensino agrícola francês, pois, segundo relatório do agrônomo Gustavo D’Utra, existia naquele país a Escola Prática de Leiteria de Coëllogon, destinada exclusivamente às mulheres, a qual tinha como objetivo:

[...] melhorar, propagar e desenvolver a indústria leiteira e completar a educação teórica e prática das moças que se destinam à vida do campo 
pelo ensino dos trabalhos domésticos (casa, costura e lavagem de roupa) e da criação de aves domésticas, vacas, porcos e abelhas, além de horticultura e jardim florífero (D’UTRA, 1908, p. 180).

Além das escolas permanentes, havia as escolas temporárias de leiteria, que tinham como finalidade o ensino dos melhores processos de alimentação racional, higiene dos animais domésticos e as práticas mais adiantadas para o fabrico de queijos e da manteiga. Estes cursos teriam a duração de três meses, sendo reservadas duas horas para o ensino teórico e três para o prático, ou seja, para a aplicação dos conhecimentos.

Diferentemente do modelo adotado para os cursos permanentes de leiteria, os cursos temporários tinham como referência a Bélgica, país que possuía escolas temporárias de leiteria para moças, com duração entre dois e três meses, reservando-se duas horas para o ensino teórico e quatro para o prático. Os programas do curso belga compreendiam noções de higiene, economia doméstica e educação, leiteria e queijaria, zootecnia, avicultura, noções de agricultura e jardinagem, contabilidade e exercícios práticos (D’UTRA, 1908).

Como se pôde verificar ao longo da exposição do decreto de criação do ensino agrícola brasileiro, foi grande a influência exercida por modelos estrangeiros, principalmente o norte-americano, o belga e o francês. Contudo, como já abordado, nota-se que a incorporação dos modelos não se deu como uma mera cópia, de forma mecânica; o que ocorreu foi uma adequação destes às peculiaridades da agricultura, da pecuária e da indústria agrícola nacional. Por isso, inferi anteriormente que não se pode afirmar que no Brasil tenha se estabelecido um modelo francês, belga ou mesmo norte-americano. Advogo que todos os exemplos estrangeiros serviram para a confecção de um modelo "à brasileira".

Para gerenciar esse modelo "à brasileira", o governo federal, nas disposições gerais do decreto ${ }^{\circ}$ 8.319, instituiu o Conselho Superior do Ensino Agronômico, que funcionaria como órgão consultivo, destinado a auxiliar a ação do governo federal na orientação e fiscalização dos diferentes estabelecimentos e serviços relacionados ao ensino.

O Conselho seria composto por representantes da sociedade civil e, hegemonicamente, por representantes de instituições vinculadas ao MAIC. Desta forma, a composição seria: três diretores gerais da Secretaria de Estado; o diretor do Serviço de Inspeção, Estatística e Defesa Agrícolas: o diretor do Jardim Botânico; o diretor do Museu Nacional; o responsável pela Diretoria de Meteorologia e Astronomia; o diretor geral do Serviço de Proteção aos Índios e Localização dos Trabalhadores Nacionais; o diretor geral do Serviço do Povoamento do Solo; o diretor da Escola Superior de Agricultura; o diretor do Posto Zootécnico Federal; um representante de associação agrícola; três representantes dos diversos ramos de agricultura, nomeados pelo Governo.

Ao longo dos trinta e seis anos em que vigorou o decreto $n^{\circ} 8.319$, até a aprovação da Lei Orgânica do Ensino Agrícola em 1946, muitas das instituições e atividades previstas sofreram modificações, impulsionadas, inclusive, pelas constantes reorganizações do MAIC. Contudo, algumas instituições, a exemplo da ESAMV (depois ENA), estações experimentais, campos de experiência, postos zootécnicos, Aprendizados Agrícolas, dentre outros, tiveram funcionamento durante todo o período, com maior ou menor visibilidade nas políticas encaminhadas pelo ministério.

Certamente, a análise estabelecida aqui, sobre o decreto que criou e organizou o ensino agronômico brasileiro, é superficial, merecendo maiores incursões sobre os exemplos estrangeiros tomados como inspiração, o funcionamento dos estabelecimentos, a clientela atendida, a visibilidade das instituições, a importância econômico-social, dentre outros elementos. 


\section{Considerações Finais}

A criação da Sociedade Nacional de Agricultura (SNA) foi um marco na luta política travada por parcela da elite agrária, levantando bandeiras, tais como: a diversificação agrícola, desenvolvimento de sindicatos e cooperativas e a criação de um ministério específico para cuidar das questões atinentes à agricultura. Esta postura da SNA colocava-a frontalmente contra os interesses dos cafeicultores paulistas, que viam em suas propostas um perigo, no tocante à distribuição de recursos públicos para manutenção da agroindústria cafeeira. Contudo, apesar do descontentamento paulista, a SNA conseguiu, no ano de 1906, ver atendida uma das suas demandas: a criação do MAIC.

Um dos pontos de convergência de interesses entre as frações da elite agrária brasileira e também dos agrônomos era a criação de instituições educacionais que qualificassem a mão de obra agrícola, estando aquela preocupada com a "reposição" de "braços" para suas lavouras e estes interessados em criar estabelecimentos que divulgassem os saberes das ciências agrícolas, além de formar uma espécie de "nicho de mercado", pois os Agrônomos deveriam ser os responsáveis pela condução do ensino agrícolas nesses locais.

Os anseios desses grupos quanto à criação de instituições de ensino deram origem ao Decreto $\mathrm{n}^{\mathbf{o}} 8.319$ de 1910 , primeira regulamentação do ensino agrícola do período republicano que criava as seguintes divisões: ensino superior, ensino médio ou teóricoprático, ensino prático, Aprendizados Agrícolas, ensino primário agrícola, escolas especiais de agricultura, escolas domésticas agrícolas, cursos ambulantes, cursos conexos com o ensino agrícola, consultas agrícolas e conferências agrícolas. Os estabelecimentos de ensino agrícola criados tinham modelos de ensino próprios que atendiam às finalidades de cada um, destacando-se o seu caráter experimental. Para tanto, os estabelecimentos deveriam dispor de serviços e instalações complementares, tais como estações experimentais, campos de experiência e demonstração, fazendas experimentais, estação de ensaio de máquinas agrícolas, postos zootécnicos e postos meteorológicos.

Muitos pontos desse regulamento apresentavam influências das ideias já adotadas em países como França, Bélgica e Estados Unidos da América, a partir de impressões e estudos realizados por representantes da elite agrária ligados aos cafeicultores paulistas e à SNA. Desta forma, o modelo de ensino agrícola brasileiro foi construído a partir dos exemplos europeu, norte-americano e paulista, visto que na época da aprovação da primeira lei do ensino agrícola, São Paulo era o estado mais desenvolvido neste setor. Com isso, não é possível afirmar que o modelo adotado no Brasil seja uma transplantação de ideias europeias ou norte-americanas, o que me leva a afirmar que se construiu em nosso país um modelo "à brasileira", ou seja, a incorporação dos modelos não se deu como uma mera cópia, de forma mecânica; o que ocorreu foi uma adequação destes às peculiaridades da agricultura, da pecuária e da indústria agrícola nacional, como por exemplo a criação dos Aprendizados Agrícolas que agregavam experiências de vários países, tais como a participação feminina e a formatação de cursos abreviados.

Contudo, ao estabelecer os Estados Unidos como um dos exemplos a ser seguido, incorporando algumas de suas ações, o modelo de ensino agrícola brasileiro absorveu também parte de suas concepções, fazendo com que as ideias pragmáticas, mesmo que de forma difusa, fossem adotadas em algumas instituições de ensino agrícola, através, por exemplo, da valorização da livre iniciativa, como na possibilidade de concessão de terras aos egressos de instituições agrícolas; do autogoverno, expresso no regime disciplinar e em atividades que ficavam sob a responsabilidade dos alunos em instituições como os 
Aprendizados Agrícolas, e da ênfase na experiência presente na concepção do "fazer para aprender", dentre outros elementos que caracterizavam o Pragmatismo como corrente filosófica norte-americana, especialmente em sua acepção deweyana.

\section{Referências}

BHERING, M. J. Positivismo e modernização: políticos e institutos científicos de agricultura no Brasil (1909-1935). 2008. 155 f. Dissertação (Mestrado em História das Ciências e da Saúde). Fundação Oswaldo Cruz, Rio de Janeiro, 2008.

BRASIL. Decreto n ${ }^{\circ} 1.606$, de 29 de dezembro de 1906. Cria uma Secretaria de Estado com a denominação de Ministério dos Negócios da Agricultura, Indústria e Comércio. SICON (Sistema de Informações do Congresso Nacional). Disponível em: $<<$ http://www.senado.gov.br/sicon>>

BRASIL. Decreto ${ }^{\circ} 8319$, de 20 de outubro de 1910. Cria o ensino agronômico e aprova o respectivo regulamento. SICON (Sistema de Informações do Congresso Nacional), 1944. Disponível em: <<http://www.senado.gov.br/sicon>>.

BRASIL-RMA. Relatório do Ministério da Agricultura. As atividades agrícolas do Brasil em 1942. Rio de Janeiro: Serviço de Informação Agrícola, vol. I, 1943.

BRASIL-RMAIC. Relatório do ministro da Agricultura Indústria e Comércio enviado ao presidente da República. Rio de Janeiro: Imprensa Oficial, 1913.

Relatório do ministro da Agricultura Indústria e Comércio enviado ao presidente da República. Rio de Janeiro: Imprensa Oficial, 1915.

Relatório do ministro da Agricultura Indústria e Comércio enviado ao presidente da República. Rio de Janeiro: Imprensa Oficial, 1916.

Relatório do ministro da Agricultura Indústria e Comércio enviado ao presidente da República. Rio de Janeiro: Imprensa Oficial, 1917.

- Relatório do ministro da Agricultura Indústria e Comércio enviado ao presidente da República. Rio de Janeiro: Imprensa Oficial, 1919.

- Relatório do ministro da Agricultura Indústria e Comércio enviado ao presidente da República. Rio de Janeiro: Imprensa Oficial, 1920.

Relatório do ministro da Agricultura Indústria e Comércio enviado ao presidente da República. Rio de Janeiro: Imprensa Oficial, 1922.

. Relatório do ministro da Agricultura Indústria e Comércio enviado ao presidente da República. Rio de Janeiro: Imprensa Oficial, 1923.

- Relatório do ministro da Agricultura Indústria e Comércio enviado ao presidente da República. Rio de Janeiro: Imprensa Oficial, 1924.

Relatório do ministro da Agricultura Indústria e Comércio enviado ao presidente da República. Rio de Janeiro: Imprensa Oficial, 1925.

Relatório do ministro da Agricultura Indústria e Comércio enviado ao presidente da República. Rio de Janeiro: Imprensa Oficial, 1926.

Relatório do ministro da Agricultura Indústria e Comércio enviado ao presidente da República. Rio de Janeiro: Imprensa Oficial, 1927. 
Relatório do ministro da Agricultura Indústria e Comércio enviado ao presidente da República. Rio de Janeiro: Imprensa Oficial, 1930-1931.

BRASIL-RMIVOP. Relatório do ministro da Indústria, Viação e Obras Públicas. Rio de Janeiro: Imprensa Nacional, 1909.

GRANATO, L. Ensino Agrícola. São Paulo: B. Mendes \& Cia., 1918.

KOIFMAN, F. (Org.). Presidentes do Brasil: de Deodoro a Juscelino. Rio de Janeiro: Editora Rio, 2001.

MELO, V. A. de. Cidade esportiva: primórdios do esporte no Rio de Janeiro. Rio de Janeiro: Relume Dumará, 2001.

MENDONÇA, S. R. de. A balança, a régua e o arado: sistema de ensino e habitus de classe na Primeira República. Cadernos do ICHF, Niterói: UFF, 48, Nov., 1992.

. O ruralismo Brasileiro (1888 - 1931). São Paulo: Hucitec, 1997.

. Agronomia e Poder no Brasil. Rio de Janeiro: Vício de Leitura, 1998.

. O Convênio de Taubaté e a Agricultura Fluminense. Revista Brasileira de Gestão e Desenvolvimento Regional v. 4. no 3 (edição especial), Taubaté, SP, p. 83-104, ago/2008.

ROSA, M. da G. de. História do ensino agrícola no Brasil República. Marília: Unesp, 1980.

SÃO PAULO. Secretaria de Agricultura, Comércio e Obras Públicas. D’UTRA, Gustavo. O Ensino Agrícola nos Estados Unidos e em alguns países da Europa. SP, 1908.

SOTH, L. A moderna agricultura e seus problemas. São Paulo: Atlas, 1968.

TURRISI, P. O Papel do Pragmatismo de Peirce na Educação. Cognitio: Revista de filosofia / Centro de Estudos do Pragmatismo, Programa de Estudos Pós-Graduados da Pontifícia Universidade Católica de São Paulo (PUCSP), n.1(2000). São Paulo: Angra EDUC, 2000, p. 122-135.

\footnotetext{
1 Doutor em Educação pela UFBA. Professor do Ensino Básico, Técnico e Tecnológico do Instituto Federal de Educação, Ciência e Tecnologia de Sergipe. Membro pesquisador do Grupo de Estudos e Pesquisas História, Sociedade e Educação do Estado de Sergipe (NPSE/UFS; rede HISTEDBR) e como lider do Grupo de Estudos e Pesquisas Sociedade, Educação e Cotidiano-GEPSEC. Email: marcoarlindo@ hotmail.com e marco.arlindo@ifs.edu.br
}

${ }^{2}$ Afonso Augusto Moreira Pena nasceu em Santa Bárbara do Mato Dentro-MG, no dia 30 de novembro de 1847. Diplomou-se em Direito pela Faculdade de Direito de São Paulo em 1870; foi um dos fundadores e diretor, em 1892, da "Faculdade Livre de Direito" de Minas Gerais, atual Faculdade de Direito da Universidade Federal de Minas Gerais (UFMG); exerceu o mandato de deputado pela província de Minas Gerais, em 1874. Nos anos seguintes, enquanto se mantinha como deputado, também ocupou alguns ministérios: da Guerra (1882); da Agricultura, Comércio e Obras Públicas (1883 e 1884), e da Justiça (1885). Foi governador do estado de Minas Gerais entre 1892 e 1894 , sendo o primeiro governador desse estado a ser eleito pelo voto direto; presidiu o Banco do Brasil, de $\underline{1895}$ a 1898 e depois tornou-se senador por Minas Gerais, chegando a vice-presidente quando da eleição de Rodrigues Alves, em 1902 (substituindo Francisco Silviano de Almeida Brandão, morto antes da posse); e na eleição seguinte, foi elevado à presidência (posse em 15 de novembro de 1906). Faleceu durante o mandato, em 1909 (.KOIFMAN, 2001).

${ }^{3}$ Francisco de Paula Rodrigues Alves nasceu em Guaratinguetá - RJ, no dia 7 de julho de 1848. Filho do português Domingos Rodrigues Alves e de Isabel Perpétua Marins, estudou no Colégio Pedro II, bacharelando-se em letras e diplomando-se na tradicional Academia do Largo de São Francisco, na turma de 1870; foi juiz de paz, promotor e vereador em Guaratinguetá, deputado provincial e geral pelo Partido 
Conservador. Empresário de sucesso do ramo do café, tornou-se a terceira maior fortuna do país. Governou São Paulo entre 1887 e 1888 como presidente da província e foi conselheiro do império. Em 1890 foi eleito deputado para a Assembléia Constituinte e, em 1891 foi nomeado ministro da Fazenda do governo de Floriano Peixoto. Em 1893 foi eleito senador por seu estado, renunciando em 1894 para ocupar novamente a pasta da Fazenda no governo Prudente de Morais; foi presidente do estado de São Paulo em 1900, antes de assumir a presidência da República em 1901. Em 1912, foi novamente eleito presidente do estado de São Paulo, ficando vários meses afastado por motivo de doença. Em 1916, encerrado o mandato de Presidente de São Paulo, voltou a ocupar uma cadeira no senado federal. Foi eleito para o segundo mandato como presidente da república em 1918, havia contraído gripe espanhola e faleceu antes de tomar posse (KOIFMAN, 2001).

${ }^{4}$ Juarez Fernandes do Nascimento Távora nasceu na fazenda do Embargo, entre Aracati e Crato, na cidade de Aguaribemirim, estado do Ceará. Estudou na Escola Militar do Realengo, no Rio de Janeiro, onde se tornou aspirante em 1919. Três anos depois tomou parte no levante contra o presidente Epitácio Pessoa. Em 1924 participou do movimento revolucionário paulista contra o presidente Artur Bernardes. Em 1926 integrou-se à Coluna Prestes. Comandou as forças nordestinas que apoiaram Getúlio Vargas (1930). Ganhou o apelido de vice-rei do Norte. Participou da repressão à Revolução Constitucionalista de 1932. Como coronel, na década de 1940, foi adido militar no Chile. Rompeu com Vargas e envolveu-se nas conspirações que levaram à deposição do ditador. Em 1954 foi um dos líderes das articulações políticas que resultaram no suicídio de Vargas. Candidatou-se à presidência da República no ano seguinte (1955), tendo sido derrotado por Juscelino Kubitschek. Elegeu-se deputado federal em 1958 e participou do golpe militar de 1964. Tornouse ministro da Viação no governo Castello Branco. Morreu no Rio de Janeiro em 18 de julho de 1975 (disponível em <www.cpdoc.fgv.br>, acesso em 26 de mio de 2009).

${ }^{5}$ Miguel Calmon Du Pin e Almeida nasceu em Salvador em 1879, formou-se engenheiro civil pela Escola Politécnica do Rio de Janeiro; foi secretário da Agricultura, Viação e Obras Públicas da Bahia (1901-1904); eleito três vezes deputado federal; ministro da Viação e Obras Públicas (1906-1909); representante da Associação Comercial da Bahia; fundador das Associações Comerciais do Brasil; vice-presidente da Liga de Defesa Nacional; integrante da Campanha Civilista; senador (1927-1930); membro do Instituto Histórico e Geográfico Brasileiro; membro do apostolado positivista; presidente da SNA (1922-1926); proprietário e usineiro (MENDONÇA, 1997).

${ }^{6}$ Ildefonso Simões Lopes nasceu em Pelotas-RS no ano de 1866. Era filho do Visconde da Graça, João Simões Lopes e de Zeferina Antônia da Luz; formou-se engenheiro civil pela Escola Politécnica do Rio de Janeiro (1890); elegeu-se deputado federal em 1906 pelo Partido Republicano Rio Grandense; a partir de 1909 dedicou-se em sua cidade natal à rizicultura, produzindo em larga escala com o implemento da mecanização e de adubos industriais; elegeu-se novamente deputado federal em 1913; ingressou na SNA em 1915, presidindo-a entre 1926 e 1943; criador da Confederação Rural Brasileira (1928); vice-presidente da comissão executiva encarregada da campanha da Aliança Liberal (1929-1930); membro do estado-maior civil revolucionário (1930); e diretor do Banco do Brasil (1930-1943), cargo que ocupava quando faleceu (MOREIRA, R. da L. Verbete "LOPES, Ildefonso Simões” In Dicionário Histórico-Biográfico Brasileiro (pós-30). Rio de Janeiro: Ed. FGV. Cd-rom).

${ }^{7}$ Estabelecimento ou posto de procriação e aperfeiçoamento das raças cavalares (disponível em <http://michaelis.uol.com.br>, acesso em 01 de jun. 2009).

${ }^{8}$ Agrostologia é o ramo da botânica relacionado com o estudo das ervas, mais especificamente com a sua classificação. Os seus objetivos são reconhecer os principais gêneros, espécies de capim leguminosas utilizados para formações de pastagem e fenação; formar pastagens e capineiras para alimentação animal; manejar adequadamente as pastagens de acordo com a classe, categoria e produção animal (disponível em <http://pt.wikipedia.org>, acesso em 1 de jun. 2009).

${ }^{9}$ Bromatologia é a disciplina científica que estuda integralmente os alimentos. Permite conhecer a sua composição qualitativa e quantitativa; o significado higiênico e toxicológico das alterações e contaminações, como e porque ocorrem e como evitá-las; qual é a tecnologia mais apropriada para tratá-los e como aplicá-la; como utilizar a legislação; segurança alimentar; protecção dos alimentos e do consumidor; quais os métodos analíticos a aplicar para determinar a sua composição e sua qualidade (disponível em <http://pt.wikipedia.org >, acesso em 1 de jun. 2009).

Recebido: julho-15 Aprovado: agosto-15 